\title{
Comments to "PRevention of INCisional hernia after liver transplantation (PRINC trial): study protocol for a randomized controlled trial."
}

\author{
Janusz Maciej Strzelczyk
}

\begin{abstract}
Prophylactic augmentation of the wound with mesh proposed by Kniepeiss et al is the world's first attempt to significantly reduce the risk of postoperative hernia in liver transplantation. Similar technique have been described 17 years ago in bariatric patients and confirmed by many studies in various clinical settings. The results of mesh hernia repair in patients on immunosuppressive therapy are not inferior from the data obtained from non- transplant surgery registers.

To reduce the risk of using the mesh in patients scheduled for liver transplantation authors chose absorbable mesh, that maintains the mechanical strength of the wound for up to 18 months. Half of the incisional hernias have been diagnoses more than 3 years from the original procedure.

For prevention of incisional hernias, there is no evidence to support the use of biologic/biosynthetic meshes.
\end{abstract}

Keywords: Prophylactic mesh, Beta-thalassemia, Laparotomy closure, Transplantation

\section{Dear Editor}

I read the article by Kniepeiss et al. with great interest. It describes the first attempt to significantly reduce the rate of postoperative hernia in patients who undergo liver transplantation [1]. The technique of primary wound augmentation with the use of mesh was first described in 2002 in a group of patients subjected to a bariatric procedure [2]. Four years later, the results of the first randomized clinical trial of hernia prophylaxis were published [3]. The effectiveness of laparotomy closure, with the use of a non-absorbable mesh, in reduction of the rate of incisional hernia has been confirmed by many studies, among them a multicenter, double-blind, randomized controlled trial by Jairam et al. [4].

The authors of the article published in Trials emphasize the risk of using the mesh in patients undergoing immunosuppressive therapy. A large study comparing the use of a mesh in repairing an incisional hernia in patients who underwent liver transplantation

Correspondence: januszst@toya.net.p

Uniwersytet Medyczny w Lodzi, Łódź, Poland or pancreatoduodenectomy showed similar results in both groups, although only patients with transplanted liver were receiving immunosuppressive therapy [5].

According to data obtained from the Americas Hernia Society Quality Collaborative, immunosuppression in patients subjected to open elective ventral hernia repair is associated with an increased risk of 30-day surgical site occurrence, mostly seromas, but not surgical site infection or an additional 30-day morbidity or mortality [6].

To reduce the risk of using the mesh in immunosuppressed patients, the authors chose a long-absorbing mesh, which maintains the mechanical strength of the wound for up to 18 months. Various studies have shown that postoperative hernia is a lifelong risk. Juvany and colleagues have found that, in half of the patients who developed incisional hernia, it occurred more than 3 years from the original procedure [7]. Kockerling et al. proved that in a complex abdominal hernia repair, biologic and biosynthetic meshes do not provide a superior alternative to synthetic meshes [8]. The use of poly-4hydroxybutyrate mesh to repair incisional hernia in a high-risk group of patients, resulted in a $9 \%$ recurrence

(c) The Author(s). 2020 Open Access This article is distributed under the terms of the Creative Commons Attribution 4.0 International License (http://creativecommons.org/licenses/by/4.0/), which permits unrestricted use, distribution, and 
rate in the 18-month follow-up [9]. There is no evidence to support the use of biologic/biosynthetic meshes for prevention of incisional hernias [8].

I am afraid that the choice of an absorbable mesh may reduce the potential success rate of incisional hernia prevention in patients who undergo liver transplantation.

Yours sincerely,

Janusz Strzelczyk, MD, PhD.

\section{Acknowledgements}

Not applicable.

\section{Author's contributions}

The author read and approved the final manuscript.

\section{Authors' information}

Not applicable.

\section{Funding}

Not applicable.

Availability of data and materials

Not applicable.

Ethics approval and consent to participate

Not applicable.

\section{Consent for publication}

Not applicable.

\section{Competing interests}

The author declares that he/she has no competing interests.

Received: 8 September 2019 Accepted: 6 January 2020

Published online: 11 February 2020

\section{References}

1. Kniepeiss D, Waha JE, Auer T, Berghold A, Schemmer P. PRevention of INCisional hernia after liver transplantation (PRINC trial): study protocol for a randomized controlled trial. Trials. 2019:20:371.

2. Strzelczyk J, Czupryniak L, Loba J, Wasiak J. The use of polypropylene mesh in midline incision closure following gastric by-pass surgery reduces the risk of postoperative hernia. Langenbecks Arch Surg. 2002;387:294-7.

3. Strzelczyk JM, Szymański D, Nowicki ME, Wilczyński W, Gaszynski T, Czupryniak L. Randomized clinical trial of postoperative hernia prophylaxis in open bariatric surgery. Br J Surg. 2006:93:1347-50.

4. Jairam AP, Timmermans L, Eker HH, Pierik REGJM, van Klaveren D, Steyerberg EW, Timman R, van der Ham AC, Dawson I, Charbon JA, Schuhmacher C, Mihaljevic A, Izbicki JR, Fikatas P, Knebel P, Fortelny RH, Kleinrensink GJ, Lange JF, Jeekel HJ, PRIMA Trialist Group. Prevention of incisional hernia with prophylactic onlay and sublay mesh reinforcement versus primary suture only in midline laparotomies (PRIMA): 2-year followup of a multicentre, double-blind, randomised controlled trial. Lancet. 2017; 390:567-76.

5. Lam HD, Vanlander A, Berrevoet F. A comparative outcome analysis of incisional hernia repair in patients who underwent liver transplantation vs. those that underwent hepatopancreaticobiliary surgery using the EHS guidelines as a means of comparison. Clin Transpl. 2016;30:226-32.

6. Haskins IN, Krpata DM, Prabhu AS, Tastaldi L, Perez AJ, Tu C, Rosenblatt S, Poulose BK, Rosen MJ. Immunosuppression is not a risk factor for 30-day wound events or additional 30-day morbidity or mortality after open ventral hernia repair: An analysis of the Americas Hernia Society Quality Collaborative. Surgery. 2018;164:594-600.

7. Juvany M, Hoyuela C, Carvajal F, Trias M, Martrat A, Ardid J. Long-term follow-up (at 5 years) of midline incisional hernia repairs using a primary closure and prosthetic onlay technique: recurrence and quality of life. Hernia. 2018;22:319-24.

8. Köckerling F, Alam NN, Antoniou SA, Daniels IR, Famiglietti F, Fortelny RH, Heiss MM, Kallinowski F, Kyle-Leinhase I, Mayer F, Miserez M, Montgomery
A, Morales-Conde S, Muysoms F, Narang SK, Petter-Puchner A, Reinpold W, Scheuerlein H, Smietanski M, Stechemesser B, Strey C, Woeste G, Smart NJ. What is the evidence for the use of biologic or biosynthetic meshes in abdominal wall reconstruction? Hernia. 2018;22:249-69.

9. Roth JS, Anthone GJ, Selzer DJ, Poulose BK, Bittner JG, Hope WW, Dunn RM, Martindale RG, Goldblatt MI, Earle DB, Romanelli JR, Mancini GJ, Greenberg JA, Linn JG, Parra-Davila E, Sandler BJ, Deeken CR, Voeller GR. Prospective evaluation of poly-4-hydroxybutyrate mesh in CDC class I/high-risk ventral and incisional hernia repair: 18-month follow-up. Surg Endosc. 2018;32: 1929-36.

\section{Publisher's Note}

Springer Nature remains neutral with regard to jurisdictional claims in published maps and institutional affiliations.
Ready to submit your research? Choose BMC and benefit from:

- fast, convenient online submission

- thorough peer review by experienced researchers in your field

- rapid publication on acceptance

- support for research data, including large and complex data types

- gold Open Access which fosters wider collaboration and increased citations

- maximum visibility for your research: over $100 \mathrm{M}$ website views per year

At BMC, research is always in progress.

Learn more biomedcentral.com/submissions 